Studia nad Autorytaryzmem i Totalitaryzmem 43, nr 3

Wrocław 2021

https://doi.org/10.19195/2300-7249.43.3.20

\author{
WIOLETTA NOWAK \\ ORCID: 0000-0002-9200-2972 \\ Uniwersytet Wrocławski \\ wioletta.nowak@uwr.edu.pl
}

\title{
Food crisis in fast-growing Turkmenistan
}

\begin{abstract}
Since the beginning of the 21 st century, Turkmenistan's economy has been growing very fast, which has been primarily generated through the extractive sector and construction industry. After the energy price collapse in mid-2014, the country has recorded a shortage of foreign currency. The authoritarian regime passed currency and economic problems onto the society. As a result, the country has experienced the most severe food crisis in its history.

The main aim of the paper is to identify the reasons behind the food crisis in Turkmenistan. The paper tries to answer the following question: how did it happen that people in one of the fastestgrowing countries in the 21 st century have been suffering from food shortages? The study is based on data retrieved from the World Bank Open Data, ILOSTAT, and Observatory of Economic Complexity, as well as a critical review of independent news websites.

The food crisis in Turkmenistan was primarily caused by hyperinflation and rationing basic groceries at preferential prices, wage arrears, cutting salaries of state employees to fund construction projects in progress, group layoffs of state employees, growing difficulties in running a private business, and depriving people of the possibility to exchange the currency at the official rate. The end of a free provision of Turkmenistan's population with electricity, gas, and drinking water has further deepened the crisis.
\end{abstract}

Keywords: economic growth, state-led economy, currency crisis, poverty, authoritarian regime.

\section{Introduction}

Turkmenistan's political system is one of the most extreme variants of authoritarianism not only in Central Asia, but also in the world. The country was ranked 162nd out of 167 countries in the 2019 Democracy Index's global ranking. ${ }^{1}$

1 The Economist Intelligence Unit, Democracy Index 2019: A year of democratic backsliding and popular protest, https://www.eiu.com/n/campaigns/democracy-index-2019/(accessed: 18.02. 2021). 
Turkmenistan is also one of the world's most isolated countries. The 2020 World Press Freedom Index ranked it 179th out of 180 countries. ${ }^{2}$ The strongly centralised political system is backed by a pervasive security apparatus. Citizens might be punished for the smallest infringements and offences against the state. ${ }^{3}$ The first president Saparmat Niyazov, known as the "father" of all Turkmens (Turkmenbashi), ruled the country from $1990^{4}$ until his death in 2006 . He created one of the most repressive regimes in the world and developed a personality cult. The presidential elections in February 2007, 2012, and 2017 were won by Gurbanguly Berdymukhamedov. The president rules Turkmenistan by decrees, provisions, and orders. From 2017, Berdymukhamedov has been intensifying his dictatorial policies in all spheres of society. The cult of the first president has been seamlessly replaced by the cult of the second one.

The Turkmen economy is one of the fastest-growing ones in the 21 st century. The country might be the "Kuwait of Central Asia" with its huge gas reserves and low population. However, exports revenues have been constantly wasted for huge infrastructure projects, large buildings, and facilities which are neither needed nor vitally important. They rather demonstrate the prosperity of the country and maintain the myth of the Golden Age. ${ }^{5}$ Since the energy price collapses in the mid2014, Turkmenistan has recorded a shortage of foreign currency. The government passed currency and economic problems onto the society. As a result, Turkmenistan experienced food and social crisis in its Era of Might and Happiness. ${ }^{6}$

The main aim of the paper is to identify reasons behind the food crisis in authoritarian Turkmenistan. The article tries to answer the following question: how did it happen that people in one of the fastest-growing countries in the $21 \mathrm{st}$ century have been suffering from food shortages? Two different types of methods were used in the analysis. Basis statistical methods were applied to show Turkmenistan's economic performance in the 21st century. Development of food crisis in the country was presented based on content analysis of texts and reports published by both opposition media operating abroad and state media.

It is worth noting that an analysis of the country's economic performance and food crisis is really difficult. Official data are scarce and very often distorted. Moreover, it is hard to find information about methods used in Turkmenistan

2 RSF: Reporters Without Borders, 2020 World Press Freedom Index, https://rsf.org/en/ranking (accessed: 18.02.2021).

${ }^{3}$ Bertelsmann Stifung, BTI 2020 Country Report - Turkmenistan, Gütersloh Stiftung, 2020, p. 3, https://www.bti-project.org/en/reports/country-report-TKM-2020.html (accessed: 17.01.2021).

${ }^{4}$ Niyazov practically ruled the country since he was appointed by Gorbachev as the first secretary of the Communist Party of the Turkmen SSR in 1985.

5 President Niyazov announced in 2000 that the 21 st century would be the Golden Age of the Turkmen people.

${ }^{6}$ As of 2020, two eras in the Golden Age have been proclaimed. Berdymukhamedov's first term in office is known as the Era of Revival (2007-2012). The Era of Might and Happiness was officially announced by Berdymukhamedov in 2012 after his victory in the second presidential election. 
to collect statistical data. The numbers are usually announced by the president of the country, and then they are repeated by ministers and state media. Datasets of international institutions such as the World Bank or the Asian Development Bank contain principally short and incomplete series of selected variables, based on the Turkmen official statistics. In the paper, GDP and GDP per capita data retrieved from the World Bank Open Data are used to study economic growth in Turkmenistan. The analysis of employment is based on data retrieved from ILOSTAT that also contains information officially reported by Turkmenistan's authorities. Data on the Turkmen merchandise exports and imports are not available in international statistics. Hence, in the paper, the estimation of the size and structure of the Turkmen foreign trade was made using data reported by Turkmenistan's trading partners. The appropriate trade data were retrieved from the Observatory of Economic Complexity. It is worth noting that obtained in this way, the scale of and trends in the Turkmen international trade are biased and incomplete, because Iran, one of Turkmenistan's trading partners, has been also providing its data selectively and irregularly. The analysis of Turkmenistan's foreign trade includes Iran's data only in the years 2001-2006 and 2010-2011.

A critical review of Vienna-based opposition news website, Chronicles of Turkmenistan, a weekly Eurasianet column called Akhal-Teke: A Turkmenistan Bulletin, Amsterdam-based news website Turkmen.news, the US-funded Radio Free Europe/Radio Liberty RFE/RL's Turkmen Service (known as Azatlyk Radio), and the State News Agency of Turkmenistan TDH, was applied to present phases of the food crisis in Turkmenistan.

\section{Determinants of economic growth in Turkmenistan}

The Turkmen economy is one of the fastest-growing Asian economies in this century. Over the period from 2001 to 2018, the average annual GDP growth rate in Turkmenistan was $8.2 \%$ and the annual GDP per capita growth rate averaged at $6.7 \%{ }^{7}$ During eighteen years, the level of GDP in constant 2010 USD increased nearly four times, whereas GDP per capita increased three times from 2458.5 (in 2001) to 7647.9 (in 2018). Since the beginning of Berdymukhamedov's first presidency to 2018, the average annual GDP and GDP per capita growth rates were $9.4 \%$ and $7.6 \%$, respectively. According to the World Bank's income classification, Turkmenistan is upper-middle-income country. It entered this category in 2012, after sustained GDP per capita growth in the years 1998-2011. It is worth noting that from 1991 to 1997 , the Turkmen economy was contracted annually by $7 \%$.

7 W. Nowak, "Inclusive growth in the fastest-growing Asian countries", Ekonomia - Wroclaw Economic Review 26, 2020, no. 3, p. 77. 
Economic growth in Turkmenistan has been generated through the extractive sector as well as building and construction industry. Turkmenistan possesses the world's fourth (after Russian Federation, Iran, and Qatar) largest gas reserves. According to the BP Statistical Review of World Energy, the confirmed reserves of gas in Turkmenistan amounted to 19.5 trillion cubic meters $(9.8 \%$ of world's reserves) at the end of 2019. Besides, Turkmenistan has deposits of oil (100 million tons). ${ }^{8}$ It is the biggest producer and exporter of gas and oil in Central Asia. In fact, natural gas is the only significant export commodity for Turkmenistan. In the years 2001-2018, petroleum gas, refined petroleum, and petroleum residues accounted for nearly $87 \%$ of Turkmenistan's total exports of goods (Figure 1).

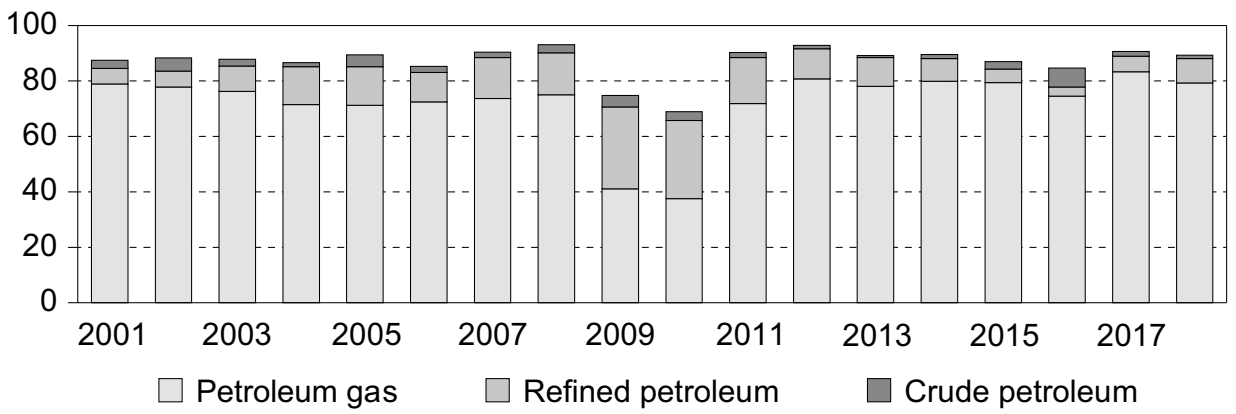

Figure 1. The share of petroleum gas, refined petroleum, and crude petroleum in Turkmenistan's total exports of goods, 2001-2018 (in \%)

Source: own elaboration based on data retrieved from The Observatory of Economic Complexity https://oec.world/en (accessed: 30.01.2021).

The Turkmen exports of goods were most diversified in the years 2009-2010. This was the period in which Turkmenistan's main trading partners were displaced by China. The explosion on the main export pipeline connecting Turkmenistan to Russia on April 9, 2009 paused the Turkmen exports of natural gas to Russia. It also deteriorated mutual relations between the countries because Turkmenistan blamed Russia for the pipeline disruption. Including trans-shipment to Europe, Russia was the biggest buyer of Turkmen gas until 2010. It substantially reduced its imports after the collapse of oil and natural gas prices in 2014, and eventually halted them in early 2016 . Since then, the countries have been negotiating new terms of gas supply. Turkmenistan resumed natural gas exports to Russia in 2019. It is worth noting that until 2011, Turkmenistan was selling its gas to Ukraine via Gazprom controlled system of natural gas pipelines. In 2009, the Central Asia-China pipeline was commissioned, which has enabled the transfer of gas from Turkmenistan to China. From 2011, China has been the most important trading partner for Turkmenistan. In the years 2012-2018, exports of commodities to China accounted for about $80 \%$ of Turkmenistan's total exports (Figure 2).

8 BP, Statistical Review of World Energy - All Data, 1965-2019, https://www.bp.com/en/ global/corporate/energy-economics/statistical-review-of-world-energy.html (accessed: 17.01.2021). 


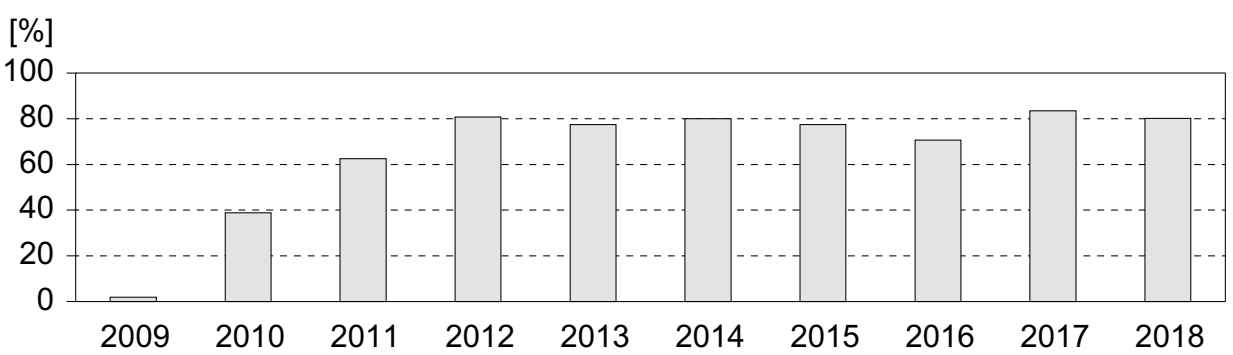

Figure 2. The share of China in Turkmenistan's total exports of goods, 2009-2018 (in \%)

Source: own elaboration based on data retrieved from The Observatory of Economic Complexity https://oec.world/en (accessed: 30.01.2021).

Recently, China has been practically the only destination for the Turkmen gas. Between 2012 and 2018, Turkmenistan exported nearly $98 \%$ of its petroleum gas to China. This causes Turkmenistan to completely depend on China and its economy. Turkmenistan under Berdymukhamedov has deteriorated its commercial relationships not only with Russia, but also with Iran. The bilateral relationship between Turkmenistan and Iran worsened in the last days of 2016, when the countries engaged in a gas dispute. Turkmenistan accused Iran of arrears amounting to nearly 2 billion USD for natural gas that Iran imported from Turkmenistan in the years 2007-2008. The Iranian side has questioned the calculation of the arrears. In January 2017, Turkmengaz, the Turkmen state company, decided to cut off gas supplies to northern Iran through the Turkmen-Iranian pipeline. ${ }^{9}$

In the years 2001-2018, two sharp declines in Turkmenistan's merchandise trade were observed. The first took place in 2009 and the second in 2015. Hence, three sub-periods can be distinguished. They cover the years 2001-2008, 20092014, and 2015-2018. During the first eight-year period, Turkmenistan's export of goods was growing at $11.3 \%$ annually. The average annual growth rate of merchandise exports was $6.6 \%$ in the years $2009-2014$ and negative $(-4.2 \%)$ between 2015 and 2018. Imports of commodities were growing at about $12 \%$ annually in the first and second periods. Between 2015 and 2018, merchandise imports were declining at about $26 \%$ annually. Trends in Turkmenistan's trade in goods are presented in Figure 3.

In the years 2001-2018, exports of goods accounted for nearly $40 \%$ of the Turkmen GDP. A bigger share of merchandise exports in GDP was in the period from 1991 to 2000 and amounted to almost $60 \% .{ }^{10}$ Revenues from exports of natural gas have been used for financing domestic investment including numerous large-scale industrial and infrastructure projects.

${ }^{9}$ Chronicles of Turkmenistan, Turkmenistan-Iran gas dispute. The lost PR war, 4.01.2017, https://en.hronikatm.com/2017/01/turkmenistan-iran-gas-dispute-the-lost-pr-war/ (accessed: 3.02. 2021).

10 Own calculations based on data retrieved from the World Bank Open Data, https://data.world bank.org/ (accessed: 8.02.2021). 


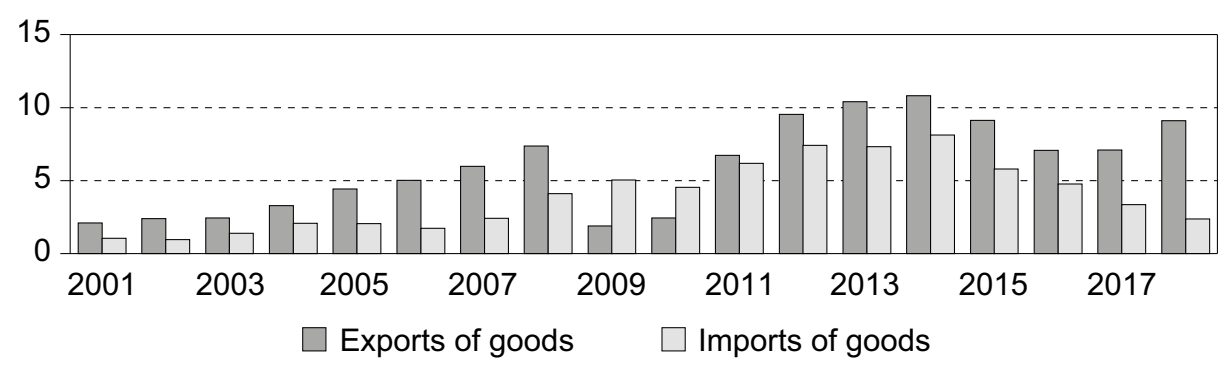

Figure 3. The value of Turkmenistan's total exports and imports of goods, 2010-2018 (in current billion USD)

Source: own elaboration based on data retrieved from The Observatory of Economic Complexity https://oec.world/en (accessed: 29.01.2021).

High energy prices in the mid-2000s allowed the Turkmen government to undertake many extensive constructions, including monumental architecture. They have continued in spite of reducing government revenues due to low oil and gas prices since mid-2014. What is more, during the currency crisis new largescale projects were initiated in Turkmenistan. According to the state information agency TDH, in 2020, about 2.5 thousand manufacturing and community facilities of the total value of 37 billion USD were under construction in Turkmenistan. ${ }^{11}$

The Turkmen economy is dominated by the public sector and state-owned monopolies. The economy develops due to the short- and long-term national and state programmes. Decision-making processes are highly centralised. Policy is made by the president and officials directly subordinate to him. ${ }^{12}$ In fact, economic growth and development in Turkmenistan has been completely determined by the president. Every major project in any area requires his decree. After independence, the Turkmen government adopted new laws targeting a gradual transformation from a centrally-planed to market-oriented economy. However, real structural reforms and denationalization of the economy failed to materialise. A small-scale privatisation has taken place in retail and service sectors, and in the most unprofitable state-owned enterprises in other sectors.

A large proportion of workers still have been employed in the public sector and state-owned enterprises. In 2019, official employment categories in Turkmenistan were the following: employees accounted for $68 \%$, employers - for $3.2 \%$, and vulnerable employment (own-account workers and contributing family workers together) represented $28.8 \%$ of total employment. ${ }^{13}$ Normally, the category of em-

11 TDH, Sovmestnoye zasedaniye Kabineta Ministrov $i$ Gosudarstvennogo soveta bezopasnosti Turkmenistana, 30.12.2020, https://th.gov.tm/ru/post/25642/sovmestnoe-zasedanie-kabinetaministrov-i-gosudarstvennogo-soveta-bezopasnosti-turkmenistana (accessed: 14.02.2021).

12 Bertelsmann Stifung, op. cit., p. 9.

13 Own calculations based on ILOSTAT, Employment by age and status in employment, https://www.ilo.org/shinyapps/bulkexplorer9/?lang=en\&segment=indicator\&id=EMP_2EMP_ AGE_STE_NB_A (accessed: 14.02.2021). 
ployers is associated with greater income security and better working conditions. However, in Turkmenistan, the public sector suffers from permanent rotations due to arbitrary reasons. Dismissals in administration are most often because of poor work results or projects not finished on time. High staff are unfairly dismissed a month or two after they were hired. One of the explanations for this phenomenon is that executives coerce bribers for work placement. ${ }^{14}$ Turkmenistan is among the most corrupt countries in the world. It was ranked the 165th out of 179 in the 2020 Corruption Perceptions Index ranking. ${ }^{15}$ Well-endowed posts in Turkmenistan can be received primarily thanks to nepotism, favouritism, and bribes.

The economy has been dominated by hydrocarbons and construction. However, the hydrocarbon sector provides employment for about $2 \%$ of the labour force. Domestic non-state enterprises are active mainly in agriculture, construction, and manufacturing. ${ }^{16}$

The analysis of an environment for business start-ups and entrepreneurs in Turkmenistan is difficult due to very limited access to regulations affecting business activity. Besides, the country is not included in the World Bank's Ease of Doing Business rankings. In general, private business is determined by Berdymukhamedov's patronage networks. Starting and running business in Turkmenistan requires good connections to the top decision-makers, relatives, or close friends among the authorities.

Generally, it is not easy to run business in Turkmenistan. No one knows when and what kind of restrictions will be suddenly announced. Even if entrepreneurs meet requirements imposed by local authorities, they never know when the decisions will be revoked and their business activity banned. For instance, since May 2019, only privately-owned stores and various service shops which were envisaged by the urban plan can be open. As a result, a lot of Turkmen were deprived of their income. They had to shut down their small businesses, located in privately-owned residential buildings, despite the fact that they previously had obtained official permits to open them. ${ }^{17}$ In February 2016, migrant workers from provinces were evicted by police officers and the municipal authorities from their rented apartments in Ashgabat due to the new apartment rental regulation

14 Chronicles of Turkmenistan, Unemployment in Ashgabat is recorded at over 50\%. Survey by “Chronicles of Turkmenistan”, 8.06.2017, https://en.hronikatm.com/2017/06/unemployment-in-ashgabat-is-recorded-at-over-50-survey-by-chronicles-of-turkmenistan/ (accessed: 25.01.2021).

15 Transparency International, Corruption Perceptions Index 2020, https://www.transparency. org/en/cpi/2020/index/nzl\# (accessed: 15.02.2021).

16 W. Nowak, "The working poor in fast growing Asian countries", [in:] The 14th International Days of Statistics and Economics: Conference Proceedings, September 10-12, 2020, Prague, eds. T. Pavelka, T. Löster, 2020, p. 774, https://msed.vse.cz/msed_2020/article/384-Nowak-Wioletta-paper.pdf (accessed: 14.02.2021).

17 Chronicles of Turkmenistan, Privately-owned stores closed down in provinces, 21.06.2019, https://en.hronikatm.com/2019/06/privately-owned-stores-closed-down-in-provinces/ (accessed: 10.02.2021). 
in the capital. Employers suddenly lost their workers. Accommodation in Ashgabat's hotels was too expensive both for companies and workers. Non-residents had to go back to their provinces. ${ }^{18}$

Private employers experience constant interference in their affairs from the state. Besides, Turkmen entrepreneurs must pay bribes from khyakimlik (local administration) to police and customs officers. A well-organized business which brings profits may always be taken over by one of the numerous president's relatives. ${ }^{19}$

\section{From currency to food crisis in the Golden Age of the Turkmen people}

The Turkmen economy heavily depends on revenues from exports of gas and oil. In the years 2014-2015, oil and gas prices drastically fell on global market. The average price of the Turkmen gas exported to China decreased from around 503 USD per metric ton in 2014 to 266 USD in $2017 .{ }^{20}$ The drop of energy prices and the necessity of repaying loans taken out to build the pipeline to China caused the balance of payments problems in Turkmenistan.

The Turkmen manat has been formally (de jure) pegged at fixed rate to US dollar. After the decline in exports revenues, the government decided to maintain the fixed parity through direct intervention and devaluated domestic currency by nearly $19 \%$ (from 2.85 to 3.50 manats for USD) at the beginning of January 2015. The authorities also limited the amount of hard-currency transactions that could be made by citizens. In January 2016, only officially employed Turkmen residents who had children studying abroad could send them 1000 USD a month via Western Union. ${ }^{21}$ Moreover, the government introduced limits and blockades on ATM cards for withdrawals from Turkmen banks abroad. The convertibility of domestic currency into dollars was suspended for private entrepreneurs (not involved in priority projects) and citizens. Since January 2016, they have not been able to purchase dollars at the official rate. The US dollars can be bought on the black market. However, the difference between the official and unofficial

18 Chronicles of Turkmenistan, Repressions against tenants result in frozen construction sites in Ashgabat, 23.02.2016, https://en.hronikatm.com/2016/02/repressions-against-tenants-result-infrozen-construction-sites-in-ashgabat/ (accessed: 5.02.2021).

19 Chronicles of Turkmenistan, Turkmen entrepreneurs flee the country, 14.03.2015, https:// en.hronikatm.com/2015/03/turkmen-entrepreneurs-flee-the-country/ (accessed: 10.02.2021).

20 J. Jakóbowski, M. Marszewski, "Crisis in Turkmenistan: A test for China's policy in the region”, OSW Commentary 2018, no. 284, p. 1, https://www.osw.waw.pl/en/publikacje/osw-commen tary/2018-08-31/crisis-turkmenistan-a-test-chinas-policy-region-0 (accessed: 20.01.2021).

${ }^{21}$ Chronicles of Turkmenistan, Restrictions to Western Union money transfer imposed in Turkmenistan, 25.01.2016, https://en.hronikatm.com/2016/01/restrictions-to-western-union-moneytransfer-imposed-in-turkmenistan/ (accessed: 16.01.2021). 
rate is several-fold. Between 2016 and February 2021, the black market rate for the US dollar increased from 6 to around 30 manats. On 14 February 2021, the US dollar was sold at 29.8 manats at the black market of Ashgabat. ${ }^{22}$

In January 2015, the Turkmen authorities have not only devaluated manat, but also increased petrol prices (from 0.62 manats to 1 manat per litre). The prices of goods and services in Turkmenistan are based mainly on the value of petrol and the dollar. Subsequently, at the beginning of 2015, food prices doubled in local markets. In April 2015, prices increased again (by 30-35\% on average) after the president's decision to review the national budget. Increase in customs duties on some import commodities (sausages, fruits, vegetables, fruit juices, and soft drinks) in October 2015 caused food prices to further increase in private-owned stores and local markets. Since then, prices have been rising, following the dollar's rate increase. Living conditions worsened significantly in 2018. Between March and September 2018, prices rose by more than $40 \%$. The growth in inflation was due to a sharp increase in the cost of imports after the collapse of the black-market exchange rate. A further increase in prices was observed in subsequent years. For instance, in grocery markets of the capital, average prices for fruit increased by $144 \%$ in 2020 , for cheese by $90 \%$, for dairy products by $70.4 \%$, for cereals and pasta by $56 \%$, for meat by $42.5 \%$, and for flour by $40 \%{ }^{23}$

Officially, salary, pension, public welfare payments, and student scholarships in Turkmenistan are annually increased by $10 \% .{ }^{24}$ However, the growth of wages has not been keeping pace with progressive hyperinflation. What is more, people have faced difficulties in access to their salaries and wage arrears. Salaries have been transferred to bank accounts from 2015. At the beginning, people were unable to get the money they earned because of a shortage of cash in ATMs. Noncash payments were not possible at most stores and bazaars due to a lack of card processing terminals. From 2015, public sector employees have experienced wage arrears of two to three months. Besides, they often must participate in obligatory crowdfunding. Employees make money contributions (20-30\% of salaries) to complete unfinished construction projects. It is worth nothing that officially "all wages, pensions, welfare payments, and student's stipends were financed timely and in full volume." 25

22 Chronicles of Turkmenistan, The dollar exchange rate fluctuates after the government session devoted to the banking sector, 14.02.2021, https://en.hronikatm.com/2021/02/the-dollar-exchangerate-fluctuates-after-the-government-session-devoted-to-the-banking-sector/ (accessed: 20.02.2021).

${ }^{23}$ Chronicles of Turkmenistan, Review of grocery prices in Turkmenistan for the fourth quarter of 2020, 16.01.2021, https://en.hronikatm.com/2021/01/review-of-grocery-prices-in-turk menistan-for-the-fourth-quarter-of-2020/ (accessed: 21.02.2021).

24 Ministry of Foreign Affairs of Turkmenistan, Social Sphere, https://www.mfa.gov.tm/en/ articles/6 (accessed: 21.02.2021).

25 Ministry of Foreign Affairs of Turkmenistan, Economy, https://www.mfa.gov.tm/en/arti cles/4 (accessed: 21.02.2021). 
The financial situation of employees, despite wage arrears and various payroll deductions, is incomparably better than that of unemployed persons. According to ILOSTAT, the official total unemployment rate in Turkmenistan was $4.4 \%$ in $2020 .{ }^{26}$ However, from 2015, constant layoffs have been observed in public authorities and state-owned companies. It is estimated that between 2015 and early 2019 , more than one in three employees lost their job. The redundancies mainly affected qualified specialist without connections to the top decisionmakers. Independent media estimated that the unemployment rate in Turkmenistan amounted to $50-60 \%$ in $2017 .{ }^{27}$

Since the beginning of the currency crisis, Turkmenistan's citizens have experienced losses of purchasing power and their jobs. Moreover, their legal support by labour migrants is difficult because remittances have been recalculating at the official rate. Additionally, the government suspended the extensive security system. ${ }^{28}$ Therefore, a large number of people cannot afford to purchase basic foodstuffs at market prices. The only option is buying subsidised groceries at state-run stores because they are several times cheaper than those in privately-owned shops and bazaars. For instance, in privately-owned shops in Ashgabat, the price of sugar was 10 manats a kilo in January 2020, while 7 manats in staterun stores. ${ }^{29} \mathrm{~A}$ bottle of Oleina oil in state-run stores was sold at 13 manats in May 2020, and in privately-owned ones at 30 manats. ${ }^{30}$ In September 2020, a kilo of meat in state-run stores cost 24 manats, whereas in privately-owned Turkmen stores, its price reached $70-80$ manats. ${ }^{31}$

People prefer to purchase basic groceries in state-run stores. However, since the beginning of the currency crisis, it has been getting harder and harder to buy them there. First shortages of subsidised food were observed in rural areas of Turkmenistan. Restrictions on selling vegetable oil and sugar (3 kilograms per person) in state-run stores were reported in August 2016. In September, there was a shortage of flour in Dashougz province. ${ }^{32}$ Sugar and cooking oil supply difficulties were recorded in the province by December 2016. To buy oil or sugar, rural residents had to put their name on the waiting list and wait four or five weeks for their turn to purchase. When oil and sugar appeared, they were rationed. One

26 ILOSTAT, Unemployment rate by sex and age, https://www.ilo.org/shinyapps/bulkexplorer 9/?lang=en\&segment=indicator\&id=EMP_2EMP_AGE_STE_NB_A (accessed: 14.02.2021).

27 Chronicles of Turkmenistan, Unemployment in Ashgabat...

28 Specific amounts of gas, electricity, and drinking water were provided to the population of Turkmenistan free of charge in the years 1992-2018.

${ }^{29}$ Chronicles of Turkmenistan, Review of grocery prices...

30 Chronicles of Turkmenistan, "Akhal" oil is again available in some state-run stores of Ashgabat, 1.06.2020, https://en.hronikatm.com/2020/06/akhal-oil-is-again-available-in-some-state-runstores-of-ashgabat/ (accessed: 19.01.2021).

31 Chronicles of Turkmenistan, Queue for meat in a state-run store (photos), 24.09.2020, https:// en.hronikatm.com/2020/09/queue-for-meat-in-a-state-run-store-photos/ (accessed: 19.01.2021).

32 Turkmenistan is divided into five provinces: Ahal, Balkan, Dashoguz, Labap, and Mary. 
family could buy up to one kilogram of sugar and five litres of cooking oil. Some state stores in the province were closed due to a lack of merchandise. ${ }^{33}$

The rationing of groceries at preferential prices at state-run stores has been gradually spreading across Turkmenistan. Moreover, except the capital and the Ahal region, a voucher system for purchasing basic foods in state shops has been introduced. In the Balkan province, a voucher system came into force at the end of April 2020. ${ }^{34}$ Households received from neighbourhood committees school notebooks with certificates inside stating the number of their members. Their each purchase of subsidised groceries was registered in these notebooks. ${ }^{35}$ The sale of basic groceries according to residence registration has also been introduced in Lebap and Mary provinces. People living in eastern regions experienced severe food shortages after a hurricane, heavy rains, and a flood in April 2020. The situation of residents of storm-ravaged areas whose buildings, cars, and livestock shelters had been damaged was extremely difficult because they did not receive government assistance. ${ }^{36}$ Moreover, authorities blocked the distribution of aid donated for them by Turkmen diaspora. ${ }^{37}$ As the food crisis in Turkmenistan intensified, local authorities started to complicate the procedure for issuing certificates. Until the end of 2020, the certificates in Dashoguz province were issued by house administrations based on the number of people registered in a household. Since January 2021, persons who left their place of residence are not entitled to rations of groceries, and certificates of household composition are issued based only on passports that can be shown. ${ }^{38}$

Province authorities do not ensure adequate supply of basic groceries for the residents. What is more, groceries at preferential prices are not regularly supplied to government-operated stores. In the last months of 2020, people were unable to buy groceries at subsidised prices in some parts of the country.

33 B. Pannier, On the Waiting List for Sugar, Cooking Oil in Turkmenistan, RFE/RL's Turkmen Service, 3.12.2016, https://www.rferl.org/a/qishloq-ovozi-waiting-list-for-sugar-cooking-oil/28154 447.html (accessed: 19.01.2021).

34 Turkmen.news, Turkmenbashi the Latest City to Introduce Food Vouchers as Unemployment Grows, 11.06.2020, https://en.turkmen.news/news/food-shortage-unemployment-turkmenistan/ (accessed: 19.01.2021).

35 RFE/RL's Turkmen Service, Turkmenistan Further Tightens Food Rationing Amid Price Hikes, Shortages, 12.06.2020, https://www.rferl.org/a/turkmenistan-further-tightens-food-rationingamid-price-hikes-shortages/30667731.html (accessed: 19.01.2021).

${ }^{36}$ RFE/RL's Turkmen Service, Turkmen in Storm-Devastated East Say Left Without State Assistance, 4.05.2020, https://www.rferl.org/a/turkmen-in-storm-devastated-east-say-left-withoutstate-assistance/30592179.htm (accessed: 19.01.2021).

37 RFE/RL's Turkmen Service, Turkmen Activists Say Authorities Blocking Aid From Abroad For Storm-Ravaged East, 12.05.2020, https:/www.rferl.org/a/turkmen-authorities-blocking-aidstorm-ravaged-east/30607895.html (accessed: 19.01.2021).

38 Chronicles of Turkmenistan, Dashoguz residents obliged to present a passport to obtain a certificate for food ration, 19.01.2021, https://en.hronikatm.com/2021/01/dashoguz-residentsobliged-to-present-a-passport-to-obtain-a-certificate-for-food-ration/ (accessed: 25.01.2021). 
Queues became a common phenomenon in Turkmenistan in 2016. By the end of 2018, people started to queue for bread, flour, eggs, cotton oil, sugar, and chicken also in the capital. Rural residents have to wait for the shop to open in a queue. They start queuing up at night and long queues are formed in front of state-run stores. Long queues have also been formed outside state stores of Ashgabat. Since December 2020, police officers have been allowing only 5 people to enter the capital's state shop at a time. Moreover, queues in Ashgabat cannot be seen from central streets and they have to be formed a few hundred meters from the shops, for instance in backyards of apartment blocks. ${ }^{39}$

Turkmenistan is dependent on food imports. The domestic production meets $40 \%$ of domestic demand for food. ${ }^{40}$ After the collapse of energy prices and the decrease in hydrocarbon revenues, the authorities have been strictly controlling imports of foodstuffs to the country. Food supplies in Turkmenistan were also constrained by poor harvests in 2015 (severe frosts and heavy rains in the winter and early spring), 2017 (a severe winter during which two thirds of all livestock fell in farming households), and in 2018 (dry weather conditions). In early 2020, the supply of food deteriorated due to the border closure with Iran. People cannot produce much food for their own needs because the state controls $90 \%$ of agricultural production and there is still a state order for cotton, wheat, and meat.

\section{Conclusion}

The state-owned media shows Turkmenistan as a prosperous welfare state and do not mention any food shortages. They claim groceries are available in unlimited quantities at market prices. However, many Turkmen, especially rural residents, cannot afford to buy them due to their low wages and poor living standards. They have to stand in long queues to purchase increasingly scarce food at subsidised prices in state-run stores.

The food crisis in Turkmenistan was caused by hyperinflation and rationing basic groceries at preferential prices, wage arrears and cutting salaries of state employees to fund construction projects in progress, group layoffs of state employees, growing difficulties in running a private business, and depriving people of the possibility to exchange the currency at the official rate. Moreover, the ending

39 Chronicles of Turkmenistan, The police requirement to form queues 300 meters away from state-run stores results in fights among customers, 21.12.2020, https://en.hronikatm.com/2020/12/ the-police-requirement-to-form-queues-300-meters-away-from-state-run-stores-results-in-fightsamong-customers/ (accessed: 23.01.2021).

40 J.C.K. Daly, "Food shortages in Turkmenistan lead to rationing in state stores", Eurasia Daily Monitor 17, 2020, no. 70, https://jamestown.org/program/food-shortages-in-turkmenistanlead-to-rationing-in-state-stores/ (accessed: 10.01.2021). 
the free provision of Turkmenistan's population with electricity, gas, and drinking water has further deepened the crisis.

Turkmenistan's economy is driven by the extractive sector and construction industry. After the decline in hydrocarbon revenues caused by the collapse of energy prices in global market, the authorities drastically limited imports of foodstuffs, although the Turkmen production does not meet the domestic demand for food. Turkmenistan has been sustaining its economic growth and continuing large-scale state investment programme at the expense of its society.

\section{References}

Bertelsmann Stifung, BTI 2020 Country Report — Turkmenistan, Gütersloh Stiftung, 2020, https:// www.bti-project.org/en/reports/country-report-TKM-2020.html.

BP, Statistical Review of World Energy - All Data, 1965-2019, https://www.bp.com/en/global/ corporate/energy-economics/statistical-review-of-world-energy.html.

Chronicles of Turkmenistan, "Akhal" oil is again available in some state-run stores of Ashgabat, 1.06.2020, https://en.hronikatm.com/2020/06/akhal-oil-is-again-available-in-some-state-runstores-of-ashgabat/.

Chronicles of Turkmenistan, Dashoguz residents obliged to present a passport to obtain a certificate for food ration, 19.01.2021, https://en.hronikatm.com/2021/01/dashoguz-residents-obligedto-present-a-passport-to-obtain-a-certificate-for-food-ration/.

Chronicles of Turkmenistan, Privately-owned stores closed down in provinces, 21.06.2019, https:// en.hronikatm.com/2019/06/privately-owned-stores-closed-down-in-provinces/.

Chronicles of Turkmenistan, Queue for meat in a state-run store (photos), 24.09.2020, https:// en.hronikatm.com/2020/09/queue-for-meat-in-a-state-run-store-photos/.

Chronicles of Turkmenistan, Repressions against tenants result in frozen construction sites in Ashgabat, 23.02.2016, https://en.hronikatm.com/2016/02/repressions-against-tenants-result-in-frozen-construction-sites-in-ashgabat/.

Chronicles of Turkmenistan, Restrictions to Western Union money transfer imposed in Turkmenistan, 25.01.2016, https://en.hronikatm.com/2016/01/restrictions-to-western-union-money-transferimposed-in-turkmenistan/.

Chronicles of Turkmenistan, Review of grocery prices in Turkmenistan for the fourth quarter of 2020, 16.01.2021, https://en.hronikatm.com/2021/01/review-of-grocery-prices-in-turkmen istan-for-the-fourth-quarter-of-2020/.

Chronicles of Turkmenistan, The dollar exchange rate fluctuates after the government session devoted to the banking sector, 14.02.2021, https://en.hronikatm.com/2021/02/the-dollar-ex change-rate-fluctuates-after-the-government-session-devoted-to-the-banking-sector/.

Chronicles of Turkmenistan, The police requirement to form queues 300 meters away from state-run stores results in fights among customers, 21.12.2020, https:/en.hronikatm.com/2020/12/thepolice-requirement-to-form-queues-300-meters-away-from-state-run-stores-results-in-fightsamong-customers/.

Chronicles of Turkmenistan, Turkmen entrepreneurs flee the country, 14.03.2015, https://en.hron ikatm.com/2015/03/turkmen-entrepreneurs-flee-the-country/.

Chronicles of Turkmenistan, Turkmenistan-Iran gas dispute. The lost PR war, 4.01.2017, https:// en.hronikatm.com/2017/01/turkmenistan-iran-gas-dispute-the-lost-pr-war/. 
Chronicles of Turkmenistan, Unemployment in Ashgabat is recorded at over 50\%. Survey by “Chronicles of Turkmenistan”, 8.06.2017, https://en.hronikatm.com/2017/06/unemploymentin-ashgabat-is-recorded-at-over-50-survey-by-chronicles-of-turkmenistan/.

Daly J.C.K., "Food shortages in Turkmenistan lead to rationing in state stores", Eurasia Daily Monitor 17, 2020, no. 70, https://jamestown.org/program/food-shortages-in-turkmenistan-lead-torationing-in-state-stores/.

ILOSTAT, Employment by age and status in employment, https://www.ilo.org/shinyapps/bulkexplo rer9/?lang=en\&segment=indicator\&id=EMP_2EMP_AGE_STE_NB_A.

ILOSTAT, Unemployment rate by sex and age, https://www.ilo.org/shinyapps/bulkexplorer9/?lang $=$ en\&segment=indicator\&id=EMP_2EMP_AGE_STE_NB_A.

Jakóbowski J., Marszewski M., "Crisis in Turkmenistan: A test for China's policy in the region", OSW Commentary 2018, no. 284, https://www.osw.waw.pl/en/publikacje/osw-commentary/ 2018-08-31/crisis-turkmenistan-a-test-chinas-policy-region-0.

Ministry of Foreign Affairs of Turkmenistan, Economy, https://www.mfa.gov.tm/en/articles/4.

Ministry of Foreign Affairs of Turkmenistan, Social Sphere, https:/www.mfa.gov.tm/en/articles/6.

Nowak W., "Inclusive growth in the fastest-growing Asian countries", Ekonomia - Wroclaw Economic Review 26, 2020, no. 3, pp. 75-86.

Nowak W., "The working poor in fast growing Asian countries", [in:] The 14th International Days of Statistics and Economics: Conference Proceedings, September 10-12, 2020, Prague, eds. T. Pavelka, T. Löster, 2020, pp. 772-782, https://msed.vse.cz/msed_2020/article/384-No wak-Wioletta-paper.pdf.

Pannier B., On the Waiting List for Sugar, Cooking Oil in Turkmenistan, RFE/RL's Turkmen Service, 3.12.2016, https://www.rferl.org/a/qishloq-ovozi-waiting-list-for-sugar-cooking-oil/281 54447.html.

RFE/RL's Turkmen Service, Turkmenistan Further Tightens Food Rationing Amid Price Hikes, Shortages, 12.06.2020, https://www.rferl.org/a/turkmenistan-further-tightens-food-rationingamid-price-hikes-shortages/30667731.html.

RFE/RL's Turkmen Service, Turkmen Activists Say Authorities Blocking Aid From Abroad For Storm-Ravaged East, 12.05.2020, https://www.rferl.org/a/turkmen-authorities-blocking-aidstorm-ravaged-east $/ 30607895 . \mathrm{html}$.

RFE/RL's Turkmen Service, Turkmen in Storm-Devastated East Say Left Without State Assistance, 4.05.2020, https://www.rferl.org/a/turkmen-in-storm-devastated-east-say-left-without-stateassistance/30592179.htm.

RSF: Reporters Without Borders, 2020 World Press Freedom Index, https://rsf.org/en/ranking.

TDH, Sovmestnoye zasedaniye Kabineta Ministrov i Gosudarstvennogo soveta bezopasnosti Turkmenistana, 30.12.2020, https://th.gov.tm/ru/post/25642/sovmestnoe-zasedanie-kabineta-min istrov-i-gosudarstvennogo-soveta-bezopasnosti-turkmenistana.

The Economist Intelligence Unit, Democracy Index 2019: A year of democratic backsliding and popular protest, https://www.eiu.com/n/campaigns/democracy-index-2019/.

The Observatory of Economic Complexity, https://oec.world/en.

Transparency International, Corruption Perceptions Index 2020, https://www.transparency.org/en/ cpi/2020/index/nzl\#.

Turkmen.news, Turkmenbashi the Latest City to Introduce Food Vouchers as Unemployment Grows, 11.06.2020, https://en.turkmen.news/news/food-shortage-unemployment-turkmenistan/.

World Bank Open Data, https://data.worldbank.org/.

Studia nad Autorytaryzmem i Totalitaryzmem 43, nr 3, 2021

(C) for this edition by CNS 